graphy) on research on eustatic sea-levels in Australia and New Zealand during 1949-52. The sectional addresses include those of Prof. M. L. Oliphant on the research school of physical science in the Australian National University; Prof. A. K. Macbeth on some aspects of the chemistry of monocyclic terpenes; Prof. F. W. Whitehouse on the Mesozoic environments of Queensland; I. M. Mackerras on zoology and medicine; Hon. P. M. Hasluck on the future of the Australian aborigine; Prof. W. Prest on the future of private enterprise; Prof. H. H. Davis on the control of dynamic loading on machine components and structure ; E. V. Keogh on virulence and infectivity; Dr. H. C. Forster's review of programmes for agricultural research in Australia; Dr. F. H. S. Roberts on host specificity of livestock parasites in Australia; Prof. V. J. Chapman on problems in ecological terminology; Prof. N. L. Edson on the metabolism of the sugar alcohols; and C. Rudduck on geography and national development. Also published is Dr. J. R. Price's Liversidge lecture on some recent developments in the study of the chemistry of Australian plant products.

\section{Legumes in Agriculture}

LEGUMES have been grown as crops for at least six thousand years, though the scientific explanation of their value was not discovered until late in the nineteenth century. How best to incorporate these important plants in the various agricultural systems of the present clay is clearly a fundamental question, and, as a step towards providing an answer, the United Nations Food and Agriculture Organization has carried ont a review of leguminous plants throughout the world. The report, published under the title "Legumes in Agriculture" (F.A.O. Agricultural Studies No. 21. Pp. 367. Rome: F.A.O.; London : H.M.S.O., $1953 ; 15 s$. or 3 dollars), is by R. O. Whyte, G. Nilsson-Leissner and H. C. Trumble. In temperate zones, with ample and well-distributed water supply, wild white clover has become the key factor in ley farming, with subterranean clover as an efficient counterpart in the pastures of South Australia. Little, however, is known regarding the use of legumes in tropical and sub-tropical regions, and literature on the subject is very meagre. In consequence, one of the most valuable parts of the publication is the section giving the results of a questionnaire sent out by the Organization during 1951 as to the occurrence and use of leguminous plants in these parts of the world. The information is conveniently reviewed on a geographical basis, and it may well be that further work on the adaptation and utilization of legumes in the tropics would best be organized on a regional basis. The chief limiting factors appear to be social and economic rather than lack of species, though there is great scope for selection and breeding within existing material. Further, it seems likely that the position of the leguminous crop in the agricultural system will differ from that in temperate lands, the trend being away from a mixed legume/grass association towards a separate but contiguous cultivation. The review should also be valuable as a book of reference, for it includes an alphabetical list of genera with notes on each, tables summarizing the characteristics of herbaceous and shrubby legumes and a bibliography.

\section{A Coniferous Petrified Forest in Patagonia}

Two species of fir cones, both of which have been named and incompletely described in earlier publica. tions, are described with anatomical details by Mary Gordon Calder in "A Coniferous Petrified Forest in Patagonia" (Bull. Brit. Mus. (Nat. Hist.) : Geol., 2, No. $2,97-138 ; 1953 ; 12 s$.$) . This account is wel-$ come as a full description of a locality where the petrified tree trunks are said to be $100 \mathrm{~m}$. long and $10 \mathrm{~m}$. round; its petrified fir cones have sometimes been sliced, polished and shown in museums as things of beauty. The forest is probably of younger Mesozoic age and was overwhelmed by volcanic ash. Of the two species of cones, one, Araucaria mirabilis, is like the Australian Araucaria bidwilli but different from the South American species of to-day. Radishlike bodies associated with the cones are recognized as the seedling hypocotyls of an Araucaria of this group; they had previously been a mystery. The other cone, with the unfortunate name of Pararaucaria, has nothing to do with Araucaria but is apparently an extinct member of the Taxodisceae, its characters being found scattered among the genera of to-day. It is interesting that this family is now absent from South America. It is good to see that two of the many fossil genera assigned to a position between Araucaria and Pinus have been removed.

\section{Natural History of Bombed Sites}

A RECENTLY published illustrated brochure summarizes in a convenient and popular manner the record of colonization of the bombed sites of London by plants and animals ("The Natural History of the City." By R. S. R. Fitter and J. E. Lousley. Pp. $36+13$ plates +1 map. London : The Corporation of London, Guildhall, E.C.2 ; 1953. $2 s$. net). The introductory chapter is largely a very condensed historical summary of the natural history of the City. It is followed by accounts of the plants, axranged according to their mode of dispersal, and the animals the presence of which is not so obviously connected with the results of bombing. In an appendix all the recorded species are listed. Though the booklet is not intended as a scientific contribution, it gives a good deal of interesting data on ecology and rate of dispersal. Clearly the opportunities to study this unexpected and ill-gotten phase in the City's development will, it is hoped, not long remain; but it is still possible among the ruins to observe rarities in both the plant and animal kingdoms.

\section{British Mammals}

- Srace the discontinuation of The Zoologist in 1916, the study of mammals in Great Britain has been greatly handicapped by the lack of a specialist journal. It is hoped to remedy this deficiency by publishing in Oryx a regular section devoted to the natural history and conservation of British mammals. The twin aims of the section are well illustrated by two articles in the current issue of Oryx, one on the field study and identification of British bats, by Michael Blackmore, the other on the case for a close season for deer, by G. K. Whitehead (2, No. 3; November 1953). In addition, it is hoped to publish regularly short notes on matters of general rather than local interest, to review books on or largely devoted to British mammals, and to abstract from local natural history journals any papers or notes of more than local interest. Editors of local journals and secretaries of the mammal sections of local natural history societies and field clubs are invited to send to Mr. R. S. R. Fitter copies of their journals or reprints of any sections of articles relating to 